\title{
ESSAY
}

\section{PARODY LOST/PRAGMATISM REGAINED: THE IRONIC HISTORY OF THE COASE THEOREM}

\author{
Daniel A. Farber
}

The world of zero transaction costs has often been described as a Coasian world. Nothing could be further from the truth. It is the world of modern economic theory, one which I was hoping to persuade economists to leave.

-Ronald Coase ${ }^{1}$

\section{INTRODUCTION}

$I^{\mathrm{N}}$

N 1960, an expatriate English economist published an article titled The Problem of Social Cost. ${ }^{2}$ The crux of the argument is now universally known as the Coase Theorem by economists and legal scholars. Coase's article became the foundation of the modern law and economics movement, and was one of the major contributions that won him the Nobel prize. The Coase Theorem also became a central target for critics who assailed the reductionism of economic theory and the imperialist designs of economists on other disciplines. In other words, if anyone has ever established a revolutionary new paradigm in legal scholarship, that person is Ronald Coase. And if there is anything that can be described as the canon of "law and economics," the Coase Theorem is at the heart of it.

The account in the preceding paragraph is a bit oversimplified but basically accurate. It is also somewhat ironic. For what be-

- Henry J. Fletcher Professor of Law, Acting Associate Vice President for Academic Affairs, and Associate Dean for Faculty and Research, University of Minnesota. I would like to thank Jim Chen, Dan Gifford, Suzanna Sherry, and Tom Ulen for their helpful comments.

' R.H. Coase, The Firm, the Market, and the Law 174 (1988).

2 R.H. Coase, The Problem of Social Cost, 3 J.L. \& Econ. 1 (1960). 
came known as the Coase Theorem was not in fact central to Coase's argument. Far from attempting to extend reductionist economic theories to law, Coase essentially advocated a pragmatist perspective on liability law-and offered what became known as the Coase Theorem almost as a kind of parody of reductionist theory. His overall body of work shows that Coase never believed the Theorem applied to the real world, and in this respect he considered it all too typical of contemporary economics. His supporters enthusiastically adopted the Coase Theorem as a paradigm, ignoring the pragmatist argument in which it was embedded. As a final irony, despite the fact that his message was misunderstood, the article sparked a debate that ultimately helped foster the kind of pragmatist scholarship he actually advocated in law and economics.

The first half of this Essay centers around the Coase Theorem. I begin with the conventional account of the Coase Theorem and its impact on legal scholarship. I then turn to the Theorem's critics and attempt to evaluate their arguments, a task that is sometimes complicated because of disputes about the meaning of the Theorem itself. As it turns out, the significance of the debate over the Theorem may relate as much to methodology as to substance, for the best of his critics often used methods surprisingly similar to those advocated by Coase.

The second half of this Essay explores the irony of the debate over Coase. Understanding this irony requires first of all a close reading of The Problem of Social Cost, which leaves little doubt about Coase's own rejection of the Coase Theorem as a paradigm for scholarship. Instead of the reductionist modeling typified by the Coase Theorem, his own approach was robustly empirical and pragmatic. I then discuss the twin ironies of Coase's success-first, that his article became a paradigm for work so distant from his own views, and second, that the efforts of his "critics," who thought they were attacking his views, in fact contributed to a reemergence of the kind of scholarship he actually advocated.

\section{The CoAse TheOREM IN A NuTSHELI}

From the beginning, the Coase Theorem was perceived as momentous. It originated in a seminar that Coase presented to 
the University of Chicago Department of Economics in 1960. Future Nobel prize winner George Stigler later called that seminar "one of the most exciting intellectual events of my life." At the beginning of the seminar, the participants took a vote on Coase's thesis. Coase received only a single vote (apparently his own). The conventional view originated by Arthur Pigou received twenty. Milton Friedman took to the attack and pummeled Coase with penetrating questions. At some point in the evening, however, Friedman changed sides and began attacking Pigou's position. By the end of the evening, the vote was Coase 21 , Pigou $0 .^{4}$

After this auspicious beginning, Coase's article quickly attained a central position in law and economics. Richard Posner has observed that the article "as everybody knows-it's silly to dwell on it-is basic to the whole economic analysis of law." Posner has also noted that The Problem of Social Cost is "widely believed to be the most frequently cited article in all of economics." By 1989, the article had received 1109 citations in the Social Science Index, about half of them in law journals. ${ }^{7}$ In absolute terms, it is probably one of the most frequently cited articles in legal scholarship. ${ }^{.}$Indeed, according to one study of the period from 1981-88, it was the single work mostly frequently cited in law review articles.'

Besides the sheer volume of citations, the article is also notable for the close attention it has received from major legal scholars, including key figures in law and economics such as Richard Posner and Bob Cooter, liberals such as Bruce Acker-

${ }^{3}$ Edmund W. Kitch, The Fire of Truth: A Remembrance of Law and Economics at Chicago, 1932-1970, 26 J.L. \& Econ. 163, 221 (1983).

4 Id.

'Id. at 226; see also Richard A. Posner, Economic Analysis of Law 8 (4th ed. 1992) (Coase Theorem is the "most celebrated application of the concept of opportunity cost in the economic analysis of law."). The concept of opportunity cost is relevant because one way of stating the Coase Theorem is that the cost of foregoing a bribe provides exactly the same incentive as the cost of paying damages, and therefore leads to the same outcomes.

${ }^{6}$ Richard A. Posner, Overcoming Law 406 (1995).

'Stewart Schwab, Coase Defends Coase: Why Lawyers Listen and Economists Do Not, 87 Mich. L. Rev. 1171, 1189 (1989).

${ }^{*}$ Id. at 1189 n.51.

' Robert C. Ellickson, Order without Law: How Neighbors Settle Disputes 2 (1991). 
man and Owen Fiss, and critical legal scholars such as Mark Kelman. As Stewart Schwab says, "[f]or both supporters and opponents, Coase has helped set the terms of debate about the legal system." 10

Little wonder that Robert Ellickson views the Coase Theorem as "undoubtedly ... the most fruitful, and the most controversial, proposition to arise out of the law-and-economics movement."1 Just what did Coase discover that was so exciting?

To understand the Coase Theorem, consider the simple case of a landowner (Mr. Boomer) who is being injured by pollution from a neighbor (the Atlantic Cement Co.). ${ }^{12}$ Here's a simple way to see the effect of liability rules. Suppose that Boomer suffers damages of $\$ 2000$ from the pollution. If Atlantic is liable for damage to Boomer, it won't pollute unless it profits from the pollution to the tune of $\$ 2000$ or more. If its profits are any lower, it will actually lose money by polluting after it pays damages to Boomer. But if the profits are higher than $\$ 2000$, Atlantic will chose to pollute, pay damages, and still come out ahead. In effect, tort liability forces Atlantic to perform a cost-benefit analysis that includes both benefits to itself and costs to others. Hence, tort liability will lead to an economically efficient outcome. ${ }^{13}$ This was essentially Pigou's point. ${ }^{14}$

Where Pigou may have gone astray, however, was in assuming that without a tax or tort liability, an inefficient level of pollution would result. It seems intuitively obvious that, without

"Schwab, supra note 7, at 1190.

"Ellickson, supra note 9 , at 2 .

12 The scenario is loosely based on Boomer v. Atlantic Cement Co., 257 N.E.2d 870 (N.Y. 1970).

${ }^{13}$ Alternatively, the government could assess a tax of $\$ 2000$ (equal to the amount of pollution harm) against Atlantic, leaving Atlantic with the choice of ceasing its pollution or paying the tax. Either way, making Atlantic "internalize" the harm to its neighbors will result in an economically efficient level of pollution.

"This point was basically correct as far as it goes, although Coase does point out a complication regarding the correct method of calculating damages. Pigou seems to have assumed that damages (or tax) would be set at the level of actual harm caused by the polluter, whereas they should actually be equal to the amount of harm given optimal mitigation measures by Boomer. Otherwise, Boomer has no incentive to avoid unnecessarily increasing the amount of damage done by the pollution. Pierre Schlag, An Appreciative Comment on Coase's The Problem of Social Cost: A View from the Left, 1986 Wis. L. Rev. 919, 921 n.5 (1986). 
some form of cost internalization, the polluter would simply ignore its neighbors. Coase observed, however, that another mechanism exists for the neighbors to influence the polluter's activities. Specifically, the possibility of bargaining between the polluter and its neighbors may substitute for damage liability as a way of reaching economic efficiency.

Coase's insight was that bargaining can produce an economically efficient outcome even without tort liability. Suppose there is no tort liability, and that Atlantic's profits are less than Boomer's $\$ 2000$ in damages. At first blush, it seems that Atlantic will choose to pollute and make its profit, even though a full cost-benefit analysis would come out negative. After all, what does Atlantic care about Boomer's harm if it doesn't have to pay damages? But there's another way to eliminate the pollution: Boomer can pay Atlantic not to pollute. For example, if Atlantic's profits are $\$ 1000$ and Boomer's harm is $\$ 2000$, Boomer could offer Atlantic $\$ 1500$ not to pollute. This is a winning deal for both sides-each is $\$ 500$ better off than in the situation where Atlantic pollutes.

This hypothetical exemplifies a more general truth. According to the Coase Theorem, assuming that transaction costs don't prevent contracting around legal rules, the legal rules don't matter-or more precisely, the parties will always bargain their way to an economically efficient outcome, regardless of the legal rule..$^{15}$ Bargaining washes out legal rules, in other words.

Applications of the Coase Theorem are often as counterintuitive as the Theorem itself. For example, a current constitutional controversy involves the power of Congress to authorize lawsuits against state governments in federal court. The Eleventh Amendment provides states with immunity from federal lawsuits, but many perplexing issues exist about how to apply the amendment in certain situations. In particular, congressional power to override state immunity has been the subject of furious debate among legal scholars. In a hotly contested opinion involving state regulation of Indian casinos, the Supreme Court recently ruled that Congress lacks this power. ${ }^{16}$ This decision

${ }^{14}$ Coase, supra note 2 , at 8.

${ }^{16}$ Seminole Tribe of Fla. v. Florida, 116 S. Ct. 1114 (1996). 
prompted an extraordinarily lengthy dissent by four Justices, and is sure to lead to a round of extensive controversy in the law reviews. The Coase Theorem suggests that this debate may be misplaced: It actually may be irrelevant whether Congress does or does not have the power to suspend state sovereign immunity unilaterally.

The debate over Congress's power to take unilateral action ignores the possibility of bilateral agreements between Congress and the states, in which Congress offers the states incentives to waive their immunity voluntarily. If the Eleventh Amendment immunity were inalienable, the Coase Theorem would not apply, since it would be impossible to bargain. But one of the few things that is really clear about the Eleventh Amendment is that it is subject to waiver by the state. ${ }^{17}$ In addition, Congress seems to be free to offer incentives for waiver. ${ }^{18}$ So bargaining is possible, and the Coase Theorem applies.

Thus, if Congress wants to badly enough, it can "bribe" the states to waive their immunity even if it does not have the power to override state immunity on its own. On the other hand, suppose Congress does have the override power, but states are strongly opposed to giving up their immunity. Then Congress will find it more advantageous to use the threat of overriding immunity as a way of getting the states to make other concessions. It follows from the Coase Theorem that sovereign immunity will be eliminated if (and only if) Congress wants to eliminate immunity more than the states want to keep itregardless of whether the Constitution gives Congress the override power!

${ }^{17}$ See generally Petty v. Tenn.-Mo. Bridge Comm'n, 359 U.S. 275, 276 (1959) (recognizing that a state may waive Eleventh Amendment immunity "at its pleasure"); Clark v. Barnard, 108 U.S. 436, 447-48 (1883) (same).

${ }^{18}$ For example, in the Seminole Tribe case itself, Congress could preempt state laws governing Indian casinos except in states waiving sovereign immunity. $116 \mathrm{~S}$. Ct. at 1131. See South Dakota v. Dole, 483 U.S. 203, 206-07 (1987) (Congress has broad power to attach conditions to spending); Parden v. Terminal Ry., 377 U.S. 184, 191-92 (1964) (Congress can require waiver of Eleventh Amendment rights as condition for state's operation in interstate commerce). Congress must express its intent to abrogate Eleventh Amendment immunity in unmistakable language in the statute itself. Welch v. Texas Dept. of Hwys. \& Pub. Transp., 483 U.S. 468 (1987). 
So, to a first approximation, the Eleventh Amendment doesn't matter, and Justices and legal scholars have been wasting their time in debating the issue. Of course, in reality, transaction costs may prevent the bargains needed for the Coase Theorem, so we can't necessarily assume that the Eleventh Amendment is totally irrelevant in practice, at least not without a careful look at possible transaction costs. ${ }^{19}$

To take another counterintuitive example from constitutional law, the power of parents to veto abortions by underage daughters has been hotly contested. In the absence of transaction costs, however, the Coase Theorem indicates that the constitutional rule is irrelevant. If the parents lack veto power but oppose the abortion more strongly than their daughter favors it, then they can offer the daughter other benefits in return for her agreement to forego the abortion. ("We promise to pay all your expenses for the baby, including day care, plus your college expenses.") If parents have the veto power, but the daughter wants an abortion more than they want to block it, the daughter can strike an advantageous deal and obtain their consent, giving them something they care about more than the abortion in return for their consent. ("I promise to start college in the fall.") All of this assumes, of course, zero transaction costs, which may seem a particularly implausible assumption given the emotional toll that "bargaining" over abortions would involve.

These examples are admittedly not typical applications of the Coase Theorem, which has not seen much use in constitutional law. ${ }^{20}$ They do aptly illustrate the startling insights which the Coase Theorem can prompt. The Eleventh Amendment example suggests that if we want to understand the true significance of sovereign immunity, we need to switch our focus from constitutional text and history to studies of bargaining between federal and state governments. The abortion example suggests that the question of parental consent is really about communica-

${ }^{19}$ See Daniel A. Farber, The Coase Theorem and the Eleventh Amendment, 13 Const. Commentary 141 (1996) (briefly sketching effects of transaction costs).

${ }^{20}$ One exception is Gregory Sidak's article on the warmaking power. J. Gregory Sidak, To Declare War, 41 Duke L.J. 27 (1991); see also J. Gregory Sidak, The Inverse Coase Theorem and Declarations of War, 41 Duke L.J. 325 (1991) (a response to critics of Sidak's article). 
tion problems between parents and children, not about autonomy from parental control. Thus, even where its conclusions do not directly apply, the Coase Theorem may suggest novel approaches to familiar issues.

In short, the Theorem is novel, counterintuitive, and a source of fruitful insights. But is it true?

\section{Testing THE COASE THEOREM}

\section{$A$. Interpreting the Theorem}

Not surprisingly, the Coase Theorem has sparked a voluminous literature, much of it devoted to attacking or defending the Theorem. Before we consider the primary challenges to the Theorem, some interpretational issues must be faced first. On some interpretations, the assumption of zero transaction costs immunizes the Theorem from critique by making it a tautology or completely counterfactual. The first question concerns the meaning of the term "zero transaction costs." Just what counts as a transaction cost? The second is whether the Theorem is limited to the situation where transaction costs are precisely zero-a situation that never arises in the real world. Or is the Theorem supposed to approximate the results in situations where transaction costs are very small?

On one interpretation, anything at all which prevents reaching a mutually advantageous bargain is a transaction cost. If so, the absence of transaction costs means that no such obstacle exists to reaching a bargain. The Coase Theorem can then be restated as follows: "Individuals will make bargains which they all desire if no obstacle of any kind to such a bargain exists." Presumably, if individuals do not make a mutually advantageous bargain, some obstacle has prevented them from doing so. So the Coase Theorem comes very close to tautology.

Stated this broadly, the Theorem seems all but immune from challenges by economic theorists. Sorting out this question is important because it also determines what, if anything, would count as an empirical test of the Theorem. If we are to test the Theorem empirically, we need to reduce or eliminate transaction costs, and this obviously requires some understanding of what counts as a transaction cost. 
The view that the Coase Theorem is a tautology is not without supporters. Jules Coleman, for instance, says the Theorem is "not an empirical claim but is instead an analytic truth about what it means, under certain conditions, to act rationally." ${ }^{21}$ This seems to be a misreading. Coase's discussion of transaction costs focuses on concrete, measurable expenditures, rather than on some abstract definition of rationality. To carry out a transaction, he observes,

it is necessary to discover who it is that one wishes to deal with, to inform people that one wishes to deal and on what terms, to conduct negotiations leading up to a bargain, to draw up the contract, to undertake the inspection needed to make sure that the terms of the contract are being observed, and so on. ${ }^{22}$

Moreover, if the notion of transaction costs were unbounded ("anything that prevents a bargain"), Coase could hardly have thought that the concept would explain when business firms rather than market transactions are used to structure production. On the tautologous interpretation, Coase's theory of the firm would reduce to: "Market transactions are used to structure production except when they aren't." This is hardly the stuff of which Nobel prizes are made.

The best interpretation of Coase, then, would seem to be that a "transaction cost" is something more than a label for failure to reach a bargain. Instead, it seems to refer to measurable costs of entering into transactions.

A related question is whether the Theorem has any application when transaction costs are low but not zero. It is conceivable that the prediction of an optimum bargain would collapse even in the presence of infinitesimal transaction costs-say, the cost of postage for mailing a billion-dollar contract. This seems

21 Jules L. Coleman, Efficiency, Exchange, and Auction: Philosophic Aspects of the Economic Approach to Law, 68 Cal. L. Rev. 221, 225 (1980). See also Herbert Hovenkamp, Marginal Utility and the Coase Theorem, 75 Cornell L. Rev. 783, 787 (1990) (Coase Theorem should be understood as a mathematical theorem rather than an empirical proposition).

"Coase, supra note 2, at 15 . As Schwab points out, Coase's more recent discussions of the Theorem also imply a nontautologous interpretation, because Coase now concedes that strategic behavior may lead to a failure of rational parties to reach a bargain even when transaction costs are zero. Schwab, supra note 7 , at 1175 . 
implausible, and supporters of the Theorem such as Posner clearly view it as applying when transaction costs are positive but small compared to the possible gains from trade..$^{23}$

\section{B. Theoretical Challenges}

Many theoretical critiques of Coase involve a point that this Essay has not yet discussed. As originally stated, the Coase Theorem can be read to imply not only that bargaining will result in an efficient allocation of resources regardless of the legal rule, but also that exactly the same allocation of resources will result regardless of what legal rule is used. As Coase now concedes, this conclusion that resource allocation is invariant across legal rules is clearly incorrect. ${ }^{24}$ Legal rights are a kind of entitlement that form part of an individual's "wealth," and the distribution of wealth affects the allocation of resources. For example, suppose Atlantic's shareholders love caviar, Boomer hates it, and pollution damages are major. Now, suppose the legal regime is one of tort liability for pollution. Boomer will collect major damages, so the shareholders will lose money and therefore buy less caviar. On the other hand, if no tort liability exists, Boomer will bribe Atlantic, which will increase the wealth of the shareholders, who will then eat more caviar. So the liability rule will affect the level of caviar production. Clean air may well be like caviar in that people who have more wealth are willing to pay more to get clean air. If so, then the distribution of wealth, which is affected by the initial distribution of legal entitlements, will also affect the victim's demand for clean air, which in turn will affect the level of pollution..$^{25}$ Thus, Coase was clearly wrong if he meant that legal rules never affect resource allocations in the absence of transaction costs. But the invariance point is really not terribly important. The real power of the Theorem is the efficiency thesis that the parties' bargain will always maximize social wealth.

\footnotetext{
2" Posner, supra note 5 , at 51 .

24 Coase, supra note 1 , at 174 . For citation to the literature on the invariance issue, see Guido Calabresi, The Pointlessness of Pareto: Carrying Coase Further, 100 Yale L.J. 1211, 1215 n.12 (1991).

${ }_{25}$ Posner, supra note 5 , at 51 .
} 
There have been two other major types of theoretical attacks on Coase. One line of attack emphasizes the economic concept of rent, a term economists use to describe any situation in which someone receives compensation for the scarcity value of a resource beyond the marginal cost of producing the resource. If there are rents, the liability rule would seem to affect the extent of the rents, and hence potentially the allocation of resources. Coase argues convincingly, however, that the existence of rents does not affect the result. ${ }^{26}$

The most interesting theoretical issue relates to strategic bargaining. This point was forcefully raised by Bob Cooter, who argued that Coase overlooked the incentives for bargainers to disguise their intentions. ${ }^{27}$ The issue of "preference revelation" is the subject of considerable attention by game theorists. ${ }^{2 s}$ In general, bargaining scenarios will not necessarily induce the parties to reveal their true preferences, which means that bargains may not be optimal. Consider what we might call the Solomon Problem-two individuals both want the same indivisible object. Optimally, the object should go to the individual who wants it more (in economic terms, the one who would pay the most). It is possible to design mechanisms which Solomon can use to force the parties to reveal their true preference levels-for example, by seizing the object and conducting an auction, dividing the revenue equally between the two people. But bargaining may not work if one party already owns the object, because bluffing on one side or the other may lead to a breakdown of negotiations, whereas the auction cannot be similarly side-tracked. ${ }^{29}$

\footnotetext{
${ }^{3 *}$ Coase, supra note 1 , at $165-170$. His position is consistent with the standard approach to rents, returns based on scarcity of resources, in economic analysis, which is to assume that the rent-producing asset is leased to firms, so that the rents are received by one person as a residual while the firm using the asset has zero rents. (Competition among firms keeps them from retaining any of the rents as they bid for the use of the asset.) The amount of pollution is determined by the lessee, who receives no rents in any event, and whose decisions about the level of pollution are thereby unaffected by any impacts on the level of rents.

${ }^{77}$ Robert Cooter, The Cost of Coase, 11 J. Legal Stud. 1, 23 (1982).

${ }^{2 x}$ See generally Joseph Farrell, Information and the Coase Theorem, 1 J. Econ. Persp. 113, 117-21 (Fall 1987) (arguing that government intervention can sometimes improve efficiency when both private and public actors have imperfect information).

2* For a detailed analysis of the game theory work, see id. at 113.
} 
Coase now seems to concede the possibility of such a breakdown in negotiations. He believes, however, that such outcomes are too rare to have much significance. ${ }^{30} \mathrm{He}$ argues that we actually see numerous exchanges taking place despite the theoretical possibility of bargaining breakdown, for example, in real estate sales and employment contracts. ${ }^{31}$ But observing that many transactions occur does not in itself provide any information about what possible transactions fail to occur. Only empirical investigation can provide this information. Moreover, only empirical investigation can show whether the assumptions of the Coase Theorem, such as rational behavior, provide a good model for actual bargaining.

\section{Empirical Issues}

The Coase Theorem can be tested empirically in two ways. First, an experimental setup may be used to study bargaining under controlled conditions. Second, real-world behavior may be carefully investigated to see whether it follows Coase's predictions.

Elizabeth Hoffman and Matthew Spitzer set up some careful experiments to test the Coase Theorem. Their experiments were highly artificial, but did confirm Coase's predictions. Indeed, they found that individuals reached efficient bargains even when the number of bargainers was fairly high, despite the fact that transaction costs might be expected to rise with increasing numbers. ${ }^{32}$ Other experiments, which were designed to study game theory rather than the Coase Theorem, raise some questions about the Coase Theorem. Some games have "cores"-group strategies which are optimal in the sense that neither any individual nor any combination of individuals can better themselves by defecting from the strategy. Game theory predicts that if a core exists, individuals should never reach an outcome outside the core, since they could always better their situations by defecting. This prediction, which is very similar to

\footnotetext{
${ }^{30}$ Coase, supra note 1 , at 161 .

"Id. at 162.

32 Elizabeth Hoffman \& Matthew L. Spitzer, Experimental Law and Economics: An Introduction, 85 Colum. L. Rev. 991, 1012-13 (1985).
} 
Coase's prediction of optimal bargains, has had only modest empirical success. ${ }^{33}$

Nonexperimental empirical results are not very supportive of Coase. Drawing on Coase's example of damage by cattle, Robert Ellickson carefully studied how ranchers responded to different rules regarding liability for damage by stray cattle. ${ }^{34} \mathrm{He}$ investigated an area where some regions were covered by a rule of strict liability for strays ("closed range") and others by a rule of nonliability with narrow exceptions ("open range"). $\mathrm{He}$ found that actual conduct regarding cattle was unaffected by the legal rule-which seems to confirm the Coase Theorem-but also that the legal rule failed to provide even a starting point for bargaining, as Coase would have predicted. Rather, individuals simply ignored the legal rule, followed precepts of neighborliness in their interactions with others, and viewed litigation as a form of deviant misconduct. ${ }^{35}$ Paradoxically, Ellickson suggests, the legal rules may have been irrelevant because transaction costs were high rather than because they were low, as Coase would suggest. ${ }^{36}$ Given the high costs of taking formal legal action, it simply wasn't worthwhile for anyone to worry about the legal rules. Indeed, although most people knew whether their land was "open" or "closed" range, hardly any of them correctly understood the legal significance of the classification.

A particularly interesting study by John Donohue straddles the line between experiment and field investigation, making use of a "natural experiment" by a state government. ${ }^{37}$ In order to study the effects of incentives on the length of periods of unemployment, the state established a program of bonuses when selected workers found jobs. One program provided for payment of the bonus to the employer, the other to the employee. The bonuses were not large enough to have significant wealth effects

"3 Donald P. Green \& Ian Shapiro, Pathologies of Rational Choice Theory: A Critique of Applications in Political Science 125-136 (1994).

${ }^{4}$ Robert C. Ellickson, Of Coase and Cattle: Dispute Resolution Among Neighbors in Shasta County, 38 Stan. L. Rev. 623 (1986).

s. Id. at 672-84.

s. Id. at 628.

${ }^{37}$ John J. Donohue III, Diverting the Coasean River: Incentive Schemes to Reduce Unemployment Spells, 99 Yale L.J. 549 (1989). 
(unlike the "caviar" example in the previous section). Because employers and employees had to bargain over employment terms anyway, additional transaction costs should have been very low. Under these circumstances, the Coasean prediction would be that outcomes in the two programs would be identical: it should make no difference whether the employer or the employee receives the check. Instead, Donohue reports, the programs operated substantially differently, with very different participation rates and different effects on unemployment. ${ }^{38}$ In particular, Donohue found that workers were more likely to take advantage of the program when the checks went directly to them rather than to the employer, even though Coase would have predicted the contrary. ${ }^{3}$

The Donohue and Ellickson studies are both inconsistent with Coase. Ellickson's findings suggest that high transaction costs may prevent legal rules from being relevant and may not be a barrier to efficient understandings between landowners. Donohue's suggest that low transaction costs may not produce efficient bargains, and that even very low transaction costs may not make legal rules irrelevant.

\section{COASE'S PROJECT: THE PROBLEM OF SOCIAL COST REVISITED}

Despite the findings in the previous section, it is undoubtedly true that people often do negotiate around legal rules to obtain mutually beneficial outcomes. Both theoretically and empirically, however, the Coase Theorem seems to fall well short of being an ironclad law of human behavior. But the Coase Theorem is only one part of Coase's article - at most a third. To see whether the imperfections of the Coase Theorem undermine his argument as a whole, a careful rereading of the article is in order. As we will see, Coase's basic project is relatively unaffected by quibbles about the validity of the Coase Theorem, partly because situations involving zero transaction costs were not his focal point.

« Id. Indeed, some individuals were so far from efficiency that they failed to even pick up checks for which they had already qualified. Id. at 572.

${ }^{3 y}$ Id. at 554. 
This point would probably be more obvious if The Problem of Social Cost were more digestible. Compared to much of the work of modern economists, the article is relatively approachable. Unlike most important works in economics since World War II, The Problem of Social Cost is written in plain English prose, unmarred by equations, and decorated with occasional flashes of wit. Nevertheless, it is not necessarily an easy piece to understand, and as we have seen, some important disputes exist about what Coase was trying to say. One problem is that the article is divided into ten short sections, whose interrelationships are not always clear. Also, although he eschews equations, Coase relies instead on arithmetic examples that many readers find more bewildering than enlightening."

In order to illuminate Coase's central argument, it is helpful to begin by explaining the theory that he was trying to rebut, and then consider how Coase's earlier work suggested some points of attack. Finally, we will take a close look at the role that the Coase Theorem plays in the argument.

\section{A. Damages, Taxes, and Externalities}

To understand what Coase calls the Pigovian position, ${ }^{41}$ let's return to the simple pollution example from the introduction of

* Consider the following passage:

The operation of the railway would enable transport services worth $\$ 250$ to be performed. It would also mean the employment of factors of production which would reduce the value of production elsewhere by $\$ 100$. Furthermore, it would mean the destruction of crops worth $\$ 120$. The coming of the railway will also have led to the abandonment of cultivation of some land.... Assume it [the value of the abandoned land] would have been $\$ 160$. But the abandonment of cultivation would have released factors of production for employment elsewhere.... Suppose that it [the increase in production elsewhere] is $\$ 150$. Then the gain from operating the railway would be $\$ 250$ (the value of the transport services) minus $\$ 100$ (the cost of the factors of production) minus $\$ 120$ (the value of crops destroyed by fire) minus $\$ 160$ (the fall in the value of crop production due to the abandonment of cultivation) plus $\$ 150$ (the value of production elsewhere of the released factors of production). Overall, operating the railway will increase the value of total production by $\$ 20$.

Coase, supra note 2, at 33 . Apart from the minority who view manually balancing their checkbooks as a recreational pursuit, most readers are unlikely to find this passage enlightening.

"Whether this was precisely Pigou's position is disputed. Compare A.W. Brian Simpson, Coase v. Pigou Reexamined, 25 J. Legal Stud. 53, 66-73 (1996) (attacking 
this Essay ${ }^{42}$ and consider how tort liability affects social welfare. Suppose that the "invisible" hand is doing its job perfectly in the rest of the economy, so that resources are allocated in the most efficient way possible given technological constraints and consumer demand. Now, focus again on the Atlantic Cement Co. and its neighbor Mr. Boomer. To make the example slightly more realistic, let's suppose that the Atlantic can operate at different levels, which result in varying amounts of profit and different degrees of harm to Boomer:

High production volume. At high volume, the company shows a profit of $\$ 2000$ and causes $\$ 2500$ worth of damage to Boomer.

Low production volume. At low volume, the company shows a profit of $\$ 1000$ and causes $\$ 500$ worth of damage.

Shut-down. If the plant doesn't operate, it causes no damage to Boomer and returns a zero profit to Atlantic.

Now, let's suppose that we want to use resources in the most productive way possible for society as a whole. We can operationalize this concept by thinking about what would happen if $\mathrm{Mr}$. Boomer also owned the Cement Co. He clearly would not want the plant to operate at high volume, because then the plant actually decreases his net economic welfare to the tune of $\$ 500$. At low volume, on the other hand, the plant would increase his net economic welfare by an equal amount. A shut-down would produce no benefit and no cost. Obviously, he's best off operating the plant at low volume. If we're interested in maximizing total social wealth, we arrive at the same conclusion even where the plant is owned by someone else, because we are focusing solely on total wealth rather than on how it is distributed between Boomer and Atlantic.

The problem, as Pigou and others have pointed out, is that except when the plant happens to be owned by Boomer, the free market provides no incentive for Atlantic to operate at a low level. Atlantic's profits, and the welfare of its shareholders, are maximized when the plant operates at high level. From the point of view of society as a whole, however, this means that

Coase's interpretation of Pigou) with R.H. Coase, Law and Economics and A.W. Brian Simpson, 25 J. Legal Stud. 103, 111-17 (1996) (responding to Simpson).

42 See supra text accompanying notes 12-14. 
cement is really being produced at more than the ideal level. The last increment of cement production, far from adding to social wealth, is actually destroying it. Not only is Boomer being harmed, but the economy as a whole is being distorted because resources are being misdirected to cement production that really could be better used elsewhere. Even though we have assumed that the invisible hand was working perfectly everywhere else in the economy, the entire economy ends up being skewed by the "externality" which Atlantic is allowed to impose on Boomer.

The way to cure this problem is obviously to force the company to operate as if it were owned by Boomer-that is, to take into account the harm to him as one of its costs of production. One possibility would be to allow Boomer to sue for damages. Alternatively, the government could impose a pollution tax equal to the amount of harm caused by the plant. Either way, the company has to "internalize" the cost it is imposing on society (in the person of Mr. Boomer). After taking this additional cost into account, the plant will cut back to a low level production, just as it would if Boomer owned the plant. ${ }^{43}$ To paraphrase our current President, the plant has been forced to "share his pain," and therefore to operate in a more socially responsible matter.

This is a highly plausible scenario. Indeed, something along these lines can be found in every introductory microeconomics book even today. The prescription is for the government to intervene wherever externalities crop up, in order to provide backup for the invisible hand of the market. As we will see, Coase was convinced that this analysis was simplistic for reasons arising out of his earlier work.

\section{B. The Evolution of Coase's Thinking}

Coase's previous work provided him with the key concepts of The Problem of Social Cost. One key concept was obviously that of transaction costs. In the other major work for which he

"For a summary of Pigou's work and the field of "welfare economics" that grew out of it, see Henry William Spiegel, The Growth of Economic Thought 572-78 (3d ed. 1991). 
was awarded the Nobel prize, he attempted to explain the existence of business firms. ${ }^{44}$ Why don't owners of material, machinery, and labor simply all contract with each other on a daily basis? In a world without transaction costs, this would be an entirely feasible alternative to the kind of ongoing organization we know as the business firm. But in the real world, it is impossibly complex and expensive to organize business operations anew on a daily basis. In order to avoid the transaction costs of the marketplace, the firm organizes resources on a more long-term basis. Society optimizes on overall transaction costs by leaving some transactions to the market and shifting others into firms. But a world without transaction costs would look nothing at all like the world we know; it would be lacking such basic economic institutions as business firms (and, Coase might also have added, money ${ }^{45}$ ).

Recall that in our analysis of the pollution hypothetical in the previous Section, we contrasted the efficient results that would occur if Boomer owned the plant with the inefficient results of separate ownership. This suggests that the heart of the pollution problem is not the brute fact that activities on one piece of land are causing physical harm on another. After all, the physical facts of pollution are not changed by a shift in ownership, but the "externality" problem could be cured by shifting ownership, internalizing the problem within a single firm. So the reason for the distortion in resource allocation is not the brute fact of pollution, but rather the social arrangements for controlling resource use. Coase's work on the nature of the firm suggests that, in looking at such social arrangements, we consider the way in which they have been molded by transaction costs. Rather than focusing on a physical problem-one person harming another-as Pigou did, we should instead be focusing on the ways in which transaction costs may be affecting economic efficiency.

* R.H. Coase, The Nature of the Firm, 4 Economica 386 (1937).

${ }^{45}$ In a world without transaction costs, barter transactions would be costless to arrange, so there would be no need for money. Instead of money changing hands five or six times, a series of five or six barter transactions could simply be arranged in advance. 
A year before The Problem of Social Cost appeared, Coase published an article on broadcasting regulation that suggested the possibility of auctioning off the spectrum to broadcasters. ${ }^{46}$ In some respect, broadcasting creates a problem much like that of pollution. Any one broadcaster can interfere with another's operations by broadcasting at the wrong frequency or power level. The conventional solution was for the government to award particular frequencies to specific broadcasters after considering the comparative merits of various applicants.

The broadcasting situation suggests that the standard pollution scenario is misleading in two important respects. First, the standard scenario views the problem as unilateral-one actor is imposing harm on another. But in the broadcasting situation, interference is not caused by one actor alone, but by the fact that two actors are making incompatible decisions about their frequency and power of operation. It is a reciprocal problem, not a unilateral one. For this reason, the standard solutions of taxes or liability rules do not seem at all intuitively obvious, because we would have to figure out some way to allocate taxes or liability between both broadcasters, who are jointly responsible for the harm. One of the reasons that Coase's numerical examples in The Problem of Social Cost are so complicated is that they embody this reciprocity. In my Atlantic Cement hypothetical, the polluter had the option of operating at different levels, but the victim was entirely passive. In Coase's more realistic hypotheticals, the amount of the damage is also influenced by the victim's decisions about how many cows to raise or what crops to plant close to a railroad.

The broadcasting scenario also suggests a need to broaden the focus in another respect as well. Broadcasting licenses are transferable. Coase suggested that, assuming the licenses are freely transferable, it really makes no difference how the government awards them-they will end up in the hands of the firms that are willing to pay the most for them. The government can auction them, which leads directly to this result. Or, the government can award them to private parties, who will in turn conduct their own auctions. In the end, the outcome is the

${ }^{*}$ R.H. Coase, The Federal Communications Commission, 2 J.L. \& Econ. 1 (1959). 
same. Coase analogized the situation to the discovery of a cave under land owned by one person but with an entrance on another person's land. The law of property dictates who owns the cave and can therefore sell it - that is, who can conduct the auction-but the result of the auction will be to put the cave in the hands of the person who can profit the most, and who will therefore be willing to pay the most. Similarly, in the pollution situation, the fact that the firm "owns" the right to control the amount of pollution (a pollution license, as it were) does not necessarily end the analysis. The firm might well "auction" its license, and the victim might end up as the highest bidder at the auction. In short, the legal allocation of property rights determines who conducts the auction but not who ends up using the property at the end of the day. ${ }^{47}$

The bottom line is that we cannot look at pollution (either of the air or of the airwaves) as an isolated physical event and design our laws accordingly. Instead, we have to see this physical event as part of a complex interaction between firms and individuals, which includes mutual adjustments in behavior as well as the possibility of voluntary reallocations of rights. The extent and form of the reallocation will be determined by transaction costs.

At this point, all of the ingredients of The Problem of Social Cost were in place. It remained only for Coase to work through concrete examples in order to show that his insight applied outside of broadcasting.

\section{The Assumption of Zero Transaction Costs}

From the amount of attention that the Coase Theorem has received, one would assume that it was the central point of Coase's article. But in fact, the Theorem had already been established by page eight of his article, and by page fifteen Coase switches gears, remarking that the argument "has proceeded up to this point on the assumption" of zero transaction costs, but "[ $t]$ his is, of course, a very unrealistic assumption." This is almost precisely a third of the way into the article; the remaining

${ }^{47}$ As we have already seen, this conclusion is not completely accurate given the opportunities for strategic behavior that are presented by different auction formats.

\$ Coase, supra note 2 , at 15 . 
two-thirds would have been unnecessary if the Coase Theorem were the main point. But if the zero-transaction case was not the main point of the article, what function does it serve in Coase's analysis?

Note that the Coase Theorem itself has been established eight pages into the article, but that Coase does not drop the "zero transaction cost" assumption for another eight pages. The intervening section is titled, "The Problem Illustrated Anew.",9 As Coase observes, this section also implicitly assumes zero transaction costs." This section is intended "[t]o clarify the nature of my argument and to demonstrate its general applicability" by illustrating it with four cases. ${ }^{\text {st }}$ Coase summarizes the first three cases as follows:

Judges have to decide on legal liability but this should not confuse economists about the nature of the economic problem involved. In the case of the cattle and the crops, it is true that there would be no crop damage without the cattle. It is equally true that there would be no crop damage without the crops. The doctor's work would not have been disturbed if the confectioner had not worked his machinery; but the machinery would have disturbed no one if the doctor had not set up his consulting room in that particular place. The matting was blackened by the fumes from the sulphate of ammonia manufacturer; but no damage would have occurred if the matting manufacturer had not chosen to hang out his matting in a particular place and to use a particular bleaching agent. ${ }^{52}$

He then restates his thesis:

If we are to discuss the problem in terms of causation, both parties cause the damage. If we are to attain an optimum allocation of resources, it is therefore desirable that both parties should take the harmful effect (the nuisance) into account in deciding on their course of action. It is one of the beauties of a smoothly operating pricing system that, as has already been

\footnotetext{
40 Id. at 8 .

(s) Id. at 15 .

${ }_{1}$ Id. at 8 .

sid. at 13 .
} 
explained, the fall in the value of production due to the harmful effect would be a cost for both parties. ${ }^{53}$

Coase then turns to his final case, a rather peculiar situation in which a brewery's ventilating shaft ceased to function properly because a neighbor built a wall, resulting in an odor problem. Coase calls this "an excellent final illustration of the problem." After describing the facts of the case and the somewhat peculiar legal resolution, he concludes by remarking that the "economic problem was to decide which to choose: a lower cost of beer and worsened amenities in adjoining houses or a higher cost of beer and improved amenities." Coase further observed that the "economic problem in all cases of harmful effects is how to maximize the value of production." The discussion closes with a reminder that the court's function is to determine who initially owns a legal right, but subsequent market transactions may modify the initial legal assignment of rights- "[a]nd of course, if such market transactions are costless, such a rearrangement of rights will always take place if it would lead to an increase in the value of production."

Thus, Coase uses the assumption of zero transaction costs to make three points. First, he shows the reciprocal nature of the problem by exploring how victims and polluters both change their behavior in response to incentives. Second, he establishes a norm for assessing institutions by comparing them to a perfect world in which the parties can unanimously agree on their preferred outcome-which turns out to be the economically efficient outcome. Third, he shows that the government is not the only possible solution-sometimes the market can handle the problem.

So much for zero transaction costs. In the real world, judicial decisions do affect total social wealth because bargaining may not occur. Coase points out that transactions are "often ex-

5 Id.

st Id. at 14.

${ }_{55}$ Id. at 15.

${ }^{\text {sh }}$ Id. Notice that Coase is careful to call this the "economic problem," which suggests that maximizing the value of production might not be the sole good from the other perspectives.

${ }^{57}$ Id. 
tremely costly, sufficiently costly at any rate to prevent many transactions that would be carried out in a world in which the pricing system worked without cost., ${ }^{, 58} \mathrm{He}$ then highlights three possible responses used when transaction costs prevent beneficial transactions: (1) a firm could acquire all of the land involved and make internal decisions about how to maximize production; (2) the government could act as a "super-firm" and make similar allocation decisions; or (3) in order to avoid the administrative costs of the first two alternatives, the problem could simply be left alone." To decide among these alternatives requires "a patient study of how, in practice, the market, firms and governments handle the problem of harmful effects. ${ }^{\prime 60}$ This study must include "the work of the broker in bringing parties together, the effectiveness of restrictive covenants, the problems of the largescale real-estate development company, the operation of Government zoning and other regulating activities."

The next section of Coase's article suggests that, where transaction costs are high, courts should make the initial assignment of rights in a way that maximizes total social wealth..$^{62}$ Coase observed that "[i]n a world in which there are costs of rearranging the rights established by the legal system, the courts, in cases relating to nuisance, are, in effect, making a decision on the economic problem and determining how resources are to be employed." Indeed, Coase says, "courts are conscious of this" and often compare, at least implicitly, "what would be gained and what lost by preventing actions which have harmful effects." ${ }^{\text {"t }}$ Most of the rest of the article consists of an attack on Pigou for overlooking the reciprocal nature of the problem by focusing on internalizing costs instead of the ultimate goal of maximizing the value of output. Rather than viewing the issue as Pigou did, as a matter of controlling the behavior of a particular

\footnotetext{
sx Id.

59 Id. at $16-18$.

on Id. at 18.

ald.

s. Id. at 19.

${ }^{63}$ Id. at 27.

at Id. at 27-28. This statement contains the germs of the "positive" theory of law and economics, which holds that the common law is economically efficient.
} 
firm, Coase argues that it is better conceptualized as a search for social arrangements that will maximize social welfare. ${ }^{65}$

The final section of Coase's article accuses Pigou and his followers of measuring unregulated markets against an ideal world, rather than adopting a more pragmatic analysis:

A better approach would seem to be to start our analysis with a situation approximating that which actually exists, to examine the effects of a proposed policy change and to attempt to decide whether the new situation would be, in total, better or worse than the original one. In this way, conclusions for policy would have some relevance to the actual situation. ${ }^{66}$

The article closes with a reminder that in choosing social arrangements, we have to remember that a change which improves some decisions may worsen others, and that no change is costless:

Furthermore we have to take into account the costs involved in operating the various social arrangements (whether it be the working of a market or of a government department), as well as the costs involved in moving to a new system. In devising and choosing between social arrangements we should have regard for the total effect. This, above all, is the change in approach which I am advocating. ${ }^{67}$

Coase's thesis can be restated as follows. Pigou's rule was that cost allocations should track physical causation. But the problem is not really one of bringing the economic world in line with predefined notions of causation and harm. Instead, the problem is how to design institutions that will maximize the overall well-being of society. The situation is actually a reciprocal one, in which the interests and actions of each party must be considered. In a perfect world, the problem would solve itself through voluntary agreements between all interested parties. In the real world, markets, firms, and governments each provide imperfect solutions. The Coase Theorem is a reminder that we

\footnotetext{
6s Id. at 34.

ns Id. at 43.

${ }^{67}$ Id. at 44.
} 
will get nowhere in analyzing the problems if we overlook the inherent imperfection of all human institutions.

\section{THE IRONY OF THE COASE THEOREM}

\section{A. Coase as Pragmatist}

Today, we are in the midst of a revival of interest in pragmatism. When reread in the current context, Coase's work has striking similarities to modern legal pragmatism. ${ }^{68}$ This subsection will briefly sketch five grounds of similarity.

The Importance of Facts. We have already seen that Coase believed a "patient examination" of actual institutions and their functioning was the key to making decisions about institutional design. He has been fiercely critical of modern economics for being too immersed in abstract theory at the expense of realism. "In my youth," he remarks, "it was said that what was too silly to be said may be sung. In modern economics it may be put into mathematics." Modern economic analysis, he says, "floats in the air," with "little investigation of how the economy actually operates. ${ }^{70}$ For instance, a classic paper uses lighthouses as an example of inherently public goods. The author overlooked the fact that in England they have actually been provided by the private sector." This example illustrates "how far economists can go wrong if they are unaware of the facts."

As to what social arrangements are best, it all depends on the facts of the particular situation. Government regulation will not necessarily give better results than the market or the firm, but "equally there is no reason why, on occasion, such governmental administrative regulation should not lead to an improvement in economic efficiency."${ }^{, 73}$

* For a brief introduction to contemporary legal pragmatism, see Daniel A. Farber, Reinventing Brandeis: Legal Pragmatism for the Twenty-First Century, 1995 U. Ill.

L. Rev. 163 (1995).

${ }^{69}$ Coase, supra note 1 , at 185 .

7) Id. at 28-29.

7Id. at 29-30.

72 Id. at 31.

73. Coase, supra note 2 , at 18 . 
Rejection of Pre-Political Rights. For traditional libertarians, rights are not the results of particular, changeable human arrangements. Rather, they derive from fundamental principles that are not subject to revamping based on circumstances. The whole point of The Problem of Social Cost is to the contrary. It is not nature that determines who should bear the liability for nuisance, but rather the particular circumstances which determine what kind of social arrangement will best suit the welfare of society. ${ }^{74}$ For this reason, Coase has even been viewed as a kind of proto-Critical legal scholar, adopting a postmodern view of law. ${ }^{75}$ While that characterization goes too far, Coase clearly is not wedded to any particular arrangement of rights or social system as inherently correct. Like many pragmatists, he sees social arrangements as means toward a better society rather than the product of some inexorable moral command.

Value Pluralism. Economists are often criticized for reducing all values to questions of economic efficiency. Pragmatists tend to believe that human beings should pursue multiple goals, which cannot necessarily be quantified or reduced in a foundationalist way to a single value. Coase does not address the matter extensively, but he seems to be in the pluralist camp:

In this article, the analysis has been confined, as is usual in this part of economics, to comparisons of the value of production, as measured by the market. But it is, of course, desirable that the choice between different social arrangements for the solution of economic problems should be carried out in broader terms than this and that the total effect of these arrangements in all spheres of life should be taken into account. As Frank $H$. Knight has so often emphasized, problems of welfare economics must ultimately dissolve into a study of aesthetics and morals. ${ }^{76}$

Rules $v$. Standards. A particularly charming part of Coase's article, but one that seems not to have been widely discussed, involves the question of liability for damages due to rabbits. A 1597 case established the rule that a landowner who stocks his manor with rabbits is not liable for the damage they do on ad-

\footnotetext{
7 Schlag, supra note 14 , at $924-25$.

${ }^{75}$ Id. at 957-58.

7 Coase, supra note 2 , at 43 .
} 
joining lands. The rationale was that, since the rabbits are wild, they are not owned by the landowner, and hence it is the rabbits themselves, rather than he, who bear the guilt for any damage." Admittedly, Coase says, the decision "seems a little odd," but then, "[a]n economist would not wish to object because legal reasoning sometimes appears a little odd.",78 Nevertheless, Coase thinks the issue of lapine liability should be brought within the general law of nuisance:

The reason is not that the man who harbours rabbits is solely responsible for the damage; the man whose crops are eaten is equally responsible [for planting the crops.] And given that the costs of market transactions make a rearrangement of rights impossible, unless we know the particular circumstances, we cannot say whether it is desirable or not to make the man who harbours rabbits responsible for the damage committed by the rabbits on neighbouring properties. The objection to the rule in Boulston's case is that, under it, the harbourer of rabbits can never be liable. It fixes the rule of liability at one pole: and this is as undesirable, from an economic point of view, as fixing the rule at the other pole and making the harbourer of rabbits always liable.... [T] he law of nuisance, as it is in fact handled by the courts, is flexible and allows for a comparison of the utility of an act with the harm it produces. ${ }^{79}$

Thus, rather than a sweeping rule of the kind that a legal formalist might prefer, Coase prefers case-by-case adjudication. Of course, he admits, the courts will make mistakes, but he asserts that "unless the courts act very foolishly, the ordinary law of nuisance would seem likely to give economically more satisfactory results than adopting a rigid rule." $\$ 0$

Humans as Social Animals. Economists are often criticized for an atomistic view of humans as selfish individuals. Many pragmatists, ranging from John Dewey to today's relational feminists, emphasize that humans are inherently cooperative social animals.

${ }^{n}$ Id. at 36.

7 Id. at 37.

${ }^{79}$ Id. at 37-38. Note that, unlike some of his followers, Coase did not necessarily favor sharply defined property rights over flexible liability rules.

*Id. at 38. 
One point of Coase's work is that humans are remarkably ingenious about finding ways to cooperate. They use a variety of mechanisms to do so, including markets, firms, and governments. Often, they manage to do so even when a theorist might expect insuperable difficulties, as in the ability of the private market to supply lighthouse services. One barrier to cooperation is obviously the desire to exploit others in order to maximize one's own benefits. Coase seems not to think that this is an overriding human motivation. In theory, bargaining could always break down because of greed or rigidity on one side or the other." In reality, as Coase points out, normally "raw materials, machinery, land, and buildings are bought and sold and even professors manage to have secretaries." the spoils does not usually get in the way of making a bargain. $\mathrm{He}$ argues that humans are innately cooperative. Personality traits that lead to an inability to make mutually beneficial bargains have little survival value, and consequently, human beings are normally willing to "split the difference.",\$3

This is a dramatically anti-Hobbesian perspective. ${ }^{.4}$ Rather than being brutish and selfish, Coase apparently believes that the natural human state is to cooperate with others and share the resulting benefits. It is startling to recall that the person with this benign view of human nature is a member of the notoriously hard-boiled University of Chicago Department of Economics!

\section{B. Coasean Ironies}

It is clear from The Problem of Social Cost itself that Coase regarded the assumption of zero transaction costs as unrealistic. Indeed, his previous work made it clear that he regarded transaction costs as not only widespread but essential to understanding the structure of the economy. More recently, he has described his view of the Coase Theorem in broader terms. In

" Usually, the range of possible prices is narrowed by market competition, but still, there is often some room for bargaining.

"2 Coase, supra note 1 , at 162 .

${ }^{3}$ Id.

s See Cooter, supra note 27, at 23 (contrasting the Coase Theorem with the "Hobbes Theorem"). 
discussing what would happen in a world of zero transaction costs, he explains, his aim

was not to describe what life would be like in such a world but to provide a simple setting in which to develop the analysis and, what was even more important, to make clear the fundamental role which transaction costs do, and should, play in the fashioning of the institutions which make up the economic system. ${ }^{85}$

He goes on to point out that a world without transaction costs "has very peculiar properties." would act like competitors, insurance companies would not exist, and there would be no economic basis for the existence of firms. ${ }^{37}$ Indeed, he says, since transactions are costless in such a world, it also costs nothing to speed them up, "so that eternity can be experienced in a split second." "It would not seem worthwhile," he concludes, "to spend much time investigating the properties of such a world."

Little wonder that Coase was dismayed to find the world of zero transaction costs described as a Coasean world. ${ }^{90}$ Instead, he says, "[i]t is the world of modern economic theory, one which I was hoping to persuade economists to leave."'11 The failure of economists to consider transaction costs is, he believes, the major reason for their inability to account for the operation of the economy in the real world. As a result, their policy proposals are "the stuff that dreams are made of."

Coase's own caustic evaluation of the so-called Coasean world raises the question whether the Coase Theorem should be considered a parody, or at least a caricature, of modern economic theory. The line between the serious and the parodic is not always clear. It is unclear what role the intent of the author or the audience's reaction plays in this distinction-the phrase

\footnotetext{
"Coase, supra note 1 , at 13.

*s Id. at 14.

nId.

\& Id. at 15 .

* Id.

"Id. at 174 .

${ }^{\prime}$ Id.

42 Id. at 185.
} 
"unintentional parody" is not an oxymoron, and many an intended parody has been taken seriously by its audience."

Perhaps it is a bit too much to call the Coase Theorem a parody. Besides using it to illustrate the fantastical nature of economic analyses that ignore transaction costs, Coase also intended it as a simple illustration of the reciprocal nature of liability issues. But Coase would probably agree that, to the extent economists take the Coase Theorem as something more than a thought experiment and view it as a serious theory about the economy, they are providing an example of some of the worst flaws of their own paradigm. If not a parody, then, the Coase Theorem has been an invitation to self-parody by its audience.

Given the fact that his intention was to shake economists out of their dominant paradigm and to move them toward a more realistic approach, the enthusiastic reception of the Coase Theorem by armchair theorists was ironic. The Coase Theorem represented the kind of ungrounded theory that Coase hoped to move economists away from. No wonder that Coase laments that "[m]y point of view has not in general commanded assent, nor has my argument, for the most part, been understood." Coase's fame as the discoverer of the Coase Theorem is a most ironic success.

As a further irony, Coase's work may have had the effect of moving some scholars in the direction he desired, not because his arguments were accepted, but because critics were moved to attack the argument they mistakenly thought he was making. When they attacked the Coase Theorem as an economic theory, they were in fact unwitting allies of Coase, who also did not believe it to be a viable economic theory. In mustering their attack on the Coase Theorem, some critics used the very tools that Coase desired-careful consideration of transaction costs and close examination of real institutions. On the theoretical side, consideration of the Coase Theorem helped lead to a re-

${ }^{93}$ For further discussion of the meaning of parody in legal scholarship, see Jordan Steiker, Sanford Levinson \& J.M. Balkin, Taking Text and Structure Really Seriously: Constitutional Interpretation and the Crisis of Presidential Eligibility, 74 Tex. L. Rev. 237, 253-257 (1995).

* Coase, supra note 1 , at 1 . 
finement of views about strategic bargaining and how it can affect outcomes, leading to a clarification of Coase's concept of transaction costs. On the empirical side, the Donohue and Ellickson studies are just the kind of conscientious empirical investigation that Coase hoped to promote. Thus, his work may have sparked the kind of attention to transaction costs and the type of empirical work he sought. The irony is that the desired reaction came as much from his critics as from his supporters.

A final irony is found in the dispute between Coase and the foremost practitioner of law and economics, Richard Posner, most of whose scholarship builds on the Coase Theorem. Unlike Coase, Posner believes that abstract economic theory is vital to understanding law and other institutions. It is unlikely, Posner says, "that serious students of transaction costs will eschew the formal methods that Coase dislikes and be content with paging through business records"-because "mathematics can lend precision to theory ... while statistical analysis can organize and interpret voluminous data." Where Coase wishes to define economics as the study of economic transactions, Posner prefers to define it as the use of rational choice methodologies to model human behavior. ${ }^{96}$ In general, Posner seems relatively uninterested in rigorously testing economic theory against reality. Yet it is Posner, not Coase, who has established a reputation as an advocate of legal pragmatism. ${ }^{77}$

Given the sharp differences between Coase and his fellow economists, one might even gently question whether The Problem of Social Cost should be viewed as a canonical work of law and economics. Perhaps instead it is among legal pragmatists where Coase should be canonized.

In a famous passage, James Madison remarked that a Constitution would be unnecessary if men were angels." At the time, apparently no one thought to dub this the "Madison Theorem," nor was he taken to advocate unrestricted government in the situation of "zero human imperfections." Scholars might have

9s Posner, supra note 6 , at 420 .

96 Id. at 417, 419, 420.

"See Richard A. Posner, The Problems of Jurisprudence (1990); Posner, supra note 6.

Q* The Federalist No. 51, at 356 (James Madison) (Benjamin F. Wright ed., 1961). 
cast some doubt on the "Madison Theorem"-theologians might have demonstrated that angels do indeed require government, ${ }^{99}$ and empirical work might have shown that relatively angelic people (monks, or perhaps law professors) have the same difficulties in governing themselves as relatively imperfect people (gangsters, or perhaps investment bankers). But all of this would have been quite irrelevant to Madison's basic point. Like Coase, he advocated the design of institutions based on a comparative study of their costs and benefits in an imperfect world. If Madison had lived in a different era, no doubt there would have been numerous articles debating the terms and validity of the "Madison Theorem." In that respect, he was luckier than Coase.

${ }^{9}$ See John Milton, Paradise Lost (1668). 